\title{
Understanding biosecurity: knowledge, attitudes and practices of seaweed farmers in the Philippines
}

\author{
Jonalyn P. Mateo ${ }^{1,2,3}$ - Iona Campbell ${ }^{4}$. Elizabeth J. Cottier-Cook ${ }^{4,5}$ - Maria Rovilla J. Luhan ${ }^{1,3}$. \\ Victor Marco Emmanuel N. Ferriols ${ }^{1} \cdot$ Anicia Q. Hurtado ${ }^{1}$
}

Received: 1 September 2020 / Revised and accepted: 7 December 2020 / Published online: 26 January 2021

(C) The Author(s) 2021

\begin{abstract}
Farmers are one of the most important components of any plant-based cultivation industry. The Philippines is one of the world's major producers of red carrageenophyte algae and has tens of thousands of farmers involved in this industry. The production of algae such as Kappaphycus and Eucheuma increased significantly from the early 1970s, when the industry was established, before declining from the mid-2000s, due to a number of reasons, including disease and epiphyte outbreaks. The introduction of biosecurity measures has been one approach used to tackle this decline. Biosecurity-related knowledge, attitude and practices (KAP) of the seaweed farmers were assessed in the four highest seaweed producing regions in the Philippines: (1) Tawi-Tawi, (2) Palawan, (3) Zamboanga and (4) Bohol. Analyses showed that seaweed farmers from Tawi-Tawi had relatively higher KAP mean scores than the other three sites. Palawan and Bohol farmers, however, scored lower on their knowledge, higher on their attitude and highest on their practices compared with the other areas. Farmers from Zamboanga scored the lowest in both their attitude and practice mean scores, although their knowledge score was one of the highest. This is the first KAP assessment applied to the seaweed farming industry globally and the results, in which the farmers' biosecurity-related knowledge and practices, which scored "Fair" (50-75\%) across all the regions, and their attitudes, which scored predominantly "Good" (> $75 \%$ ) suggest that there is potential to raise the score for biosecurity practices. This assessment highlights how biosecurity challenges are currently addressed by seaweed farmers in the Philippines and suggests how the KAP survey could be used as a tool by policymakers and scientists to address gaps in biosecurity management practices.
\end{abstract}

Keywords Knowledge $\cdot$ Attitudes $\cdot$ Practice $\cdot$ Seaweed industry $\cdot$ Biosecurity

Jonalyn P. Mateo

jpmateo@up.edu.ph

Elizabeth J. Cottier-Cook

elizabeth.cottier-cook@uhi.ac.uk

1 Institute of Aquaculture, University of the Philippines Visayas, 5023 Miagao, Iloilo, Philippines

2 Institute of Marine Fisheries and Oceanology, University of the Philippines Visayas, 5023 Miagao, Iloilo, Philippines

3 Aquaculture Department, Southeast Asian Fisheries Development Center, 5021 Tigbauan, Iloilo, Philippines

4 Scottish Association for Marine Science, Scottish Marine Institute, Oban, Argyll PA37 1QA, Scotland

5 University of Highlands and Islands, Oban, Argyll PA37 1QA, Scotland

\section{Introduction}

There is a long history of red algae (e.g. Kappaphycus and Eucheuma) production in tropical and sub-tropical countries (Hayashi et al. 2017), which has provided considerable economic benefits to tens of thousands of seaweed farmers in developing countries (Hurtado 2013; Msuya 2013; Neish 2013; Valderrama et al. 2013, 2015; Cottier-Cook et al. 2016; Samonte 2017). As a consequence of the rapid growth of this industry over the last 50 years, trans-boundary, intentional introductions of certain red algae species, especially Kappaphycus spp., have occurred for commercial purposes (Smith et al. 2002; Ask et al. 2003). Biosecurity measures, however, have been absent or, not strictly implemented, from the point of origin to final out-planting sites (Mateo et al. 2020). This lack of biosecurity has led to disease and pest introductions, together with the intentionally introduced algae, which in many cases, have only become apparent several years after arrival (Vairappan et al. 2008; Tsiresy et al. 2016). 
The peak of seaweed production $(1.84 \mathrm{M} \mathrm{t} \mathrm{fwt})$ in the Philippines was reported in 2011; however, production reduced significantly in 2012 (4.9\%, with a value equivalent of US\$80,470M) (Philippines Statistics Authority (PSA) 2013) due to disease outbreaks and has since continued to decline. This situation has been further exacerbated by poor cultivar quality, which has resulted in a greater susceptibility of the cultivated seaweeds to disease and pest infestation, to abiotic and biotic stresses and to climate change, as reviewed by Largo et al. (2017). Consequently, farmers have had to source high quality cultivars from other regions, thus increasing the likelihood of introducing infected strains to their farm. Since no, or minimal, biosecurity regulations are typically implemented in the Philippines, the translocation of strains and their health status at the local and regional levels continues unchecked (Mateo et al. 2020).

The UN Fisheries and Agriculture Organization (FAO) (2019) defines biosecurity as the cost-effective management of risks posed by pathogenic agents to aquaculture through a strategic approach at enterprise, national, international levels with shared public-private responsibilities. The application of biosecurity measures is seen as an essential element of food safety, especially in aquaculture and measures have successfully been implemented, for example in fin-fish (Rahman and Rahman 2018; Tidbury et al. 2018), shrimp (Tendencia and Estilo 2017; Sanz 2018) and molluscs (Hardy-Smith et al. 2019). Biosecurity measures related to seaweed aquaculture, however, are absent from the literature, with the exception of Sulu et al. (2004), which describes basic quarantine protocols. Campbell et al. (2020) reported four biosecurity policy challenges faced by the seaweed industry globally, which should be addressed to make the industry more robust and sustainable. These challenges included (1) inconsistent terminology for the inclusion of seaweeds in regulatory frameworks, (2) limited guidance for the responsibility of implementation of biosecurity measures, (3) insufficient evidence to develop disease and pest-specific policies and (4) lack of a coherent approach to seaweed biosecurity risk management in international policies. The report of Kambey et al. (2020) and Mateo et al. (2020) demonstrated similar issues, as far as national biosecurity-related regulations and policies were concerned in Indonesia and the Philippines, respectively. These issues included (1) a lack of a "recognized" national authority to enforce regulations; (2) a lack of seaweed-specific prevention, detection and verification measures; and (3) a lack of national capacity for the implementation and the use of the precautionary principle relating to uncertainty in the collective risks faced by the seaweed industry.

This study was conducted to determine the current biosecurity-related knowledge, attitudes and practices of seaweed farmers in the top four major producing regions of the Philippines. The method employed in the current study has previously been used to assess community awareness in a variety of subject areas from nutrition (Liu et al. 2018), human diseases (e.g. diabetes, HIV) (Arbiol et al. 2016; Srinivasan et al. 2017; Amiri et al. 2018), driving skills (Mirzaei et al. 2014) to agriculture (Meijer et al. 2015; Arif et al. 2017; Tran et al. 2018). To date, only one previous study has used this method to understand an aquaculture-related issue, specifically involving the production of yellow catfish in China (Jia et al. 2017). It is envisaged that this study will help to identify the biosecurity-related knowledge gaps in the seaweed farming communities in the Philippines and to enable the development of scientifically robust solutions to minimise the introduction and spread of pests and disease in the future.

\section{Materials and methods}

A modified knowledge-based understanding, attitude and practice (KAP) assessment based on Jia et al. (2017) was conducted in four of the highest seaweed-producing regions of the Philippines: (a) Tawi-Tawi (Bangsamoro Autonomous Region of Muslim Mindanao, $6.96^{\circ} \mathrm{N}, 124.24^{\circ} \mathrm{E}$ ), (b) Zamboanga (Region IX, $8.15^{\circ} \mathrm{N}, 123.26^{\circ} \mathrm{E}$ ), (c) Palawan (Region IVB, $9.84^{\circ} \mathrm{N}, 118.74^{\circ} \mathrm{E}$ ) and (d) Bohol (Region VII-Central Visayas, $9.82^{\circ} \mathrm{N}, 124.06^{\circ} \mathrm{E}$ ).

A total of 120 seaweed farmers were interviewed from July 2018 to October 2019 in the targeted areas (Fig. 1) using a closed-ended questionnaire through a convenience sampling. A seaweed farmer is described in the present study as the one who does the major farming activities from selection of "seedlings", installation of cultivation ropes to the farm site, maintenance (cleaning) of the seaweeds, harvesting, packing/bagging and bringing the dried seaweed to the traders in the community. An onsite guide/translator led the interviewer to the farmer's residence/farm for one-on-one interviews. Before commencing the interview, the interviewer explained the protocol regarding the survey and gained formal consent by the farmer. The questionnaire included (a) demographic data (e.g. age, gender, educational attainment, number of years' experience farming seaweed and (b) phyconomic practices, including farm management, operations and bio-security measures.

Data derived from the KAP assessment were indexed, and the formula of Jia et al. (2017) was adapted through scoring and computations mentioned below. Knowledge answers were scored 0 (no and not sure) and 1 (yes). Attitude responses were scored 5 (very useful), 3 


\section{SEAWEED}

PRODUCTION

i.

$-8$

IN THE

PHILIPPINES 2017 \& $\theta^{\circ}$

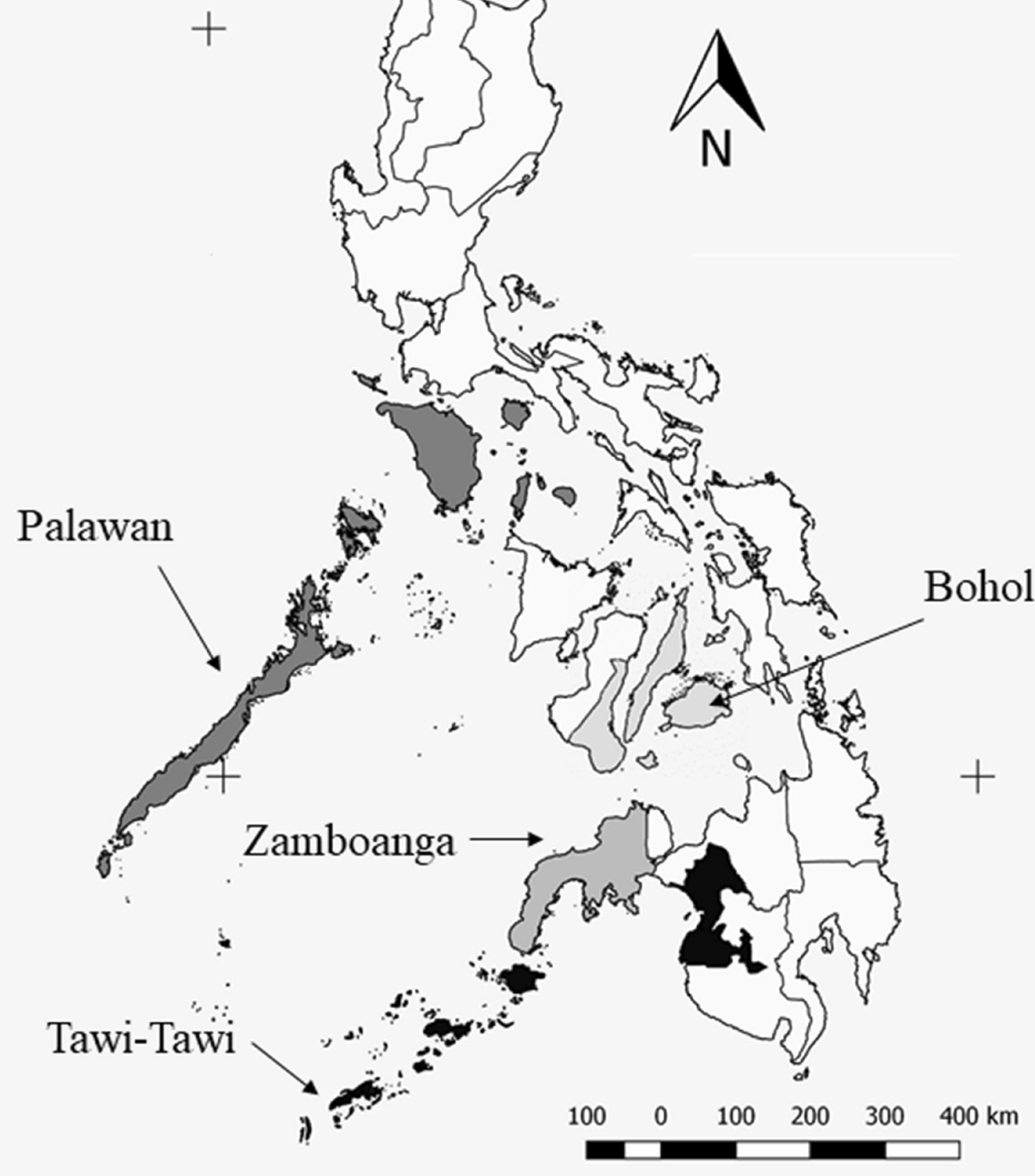

Palawan

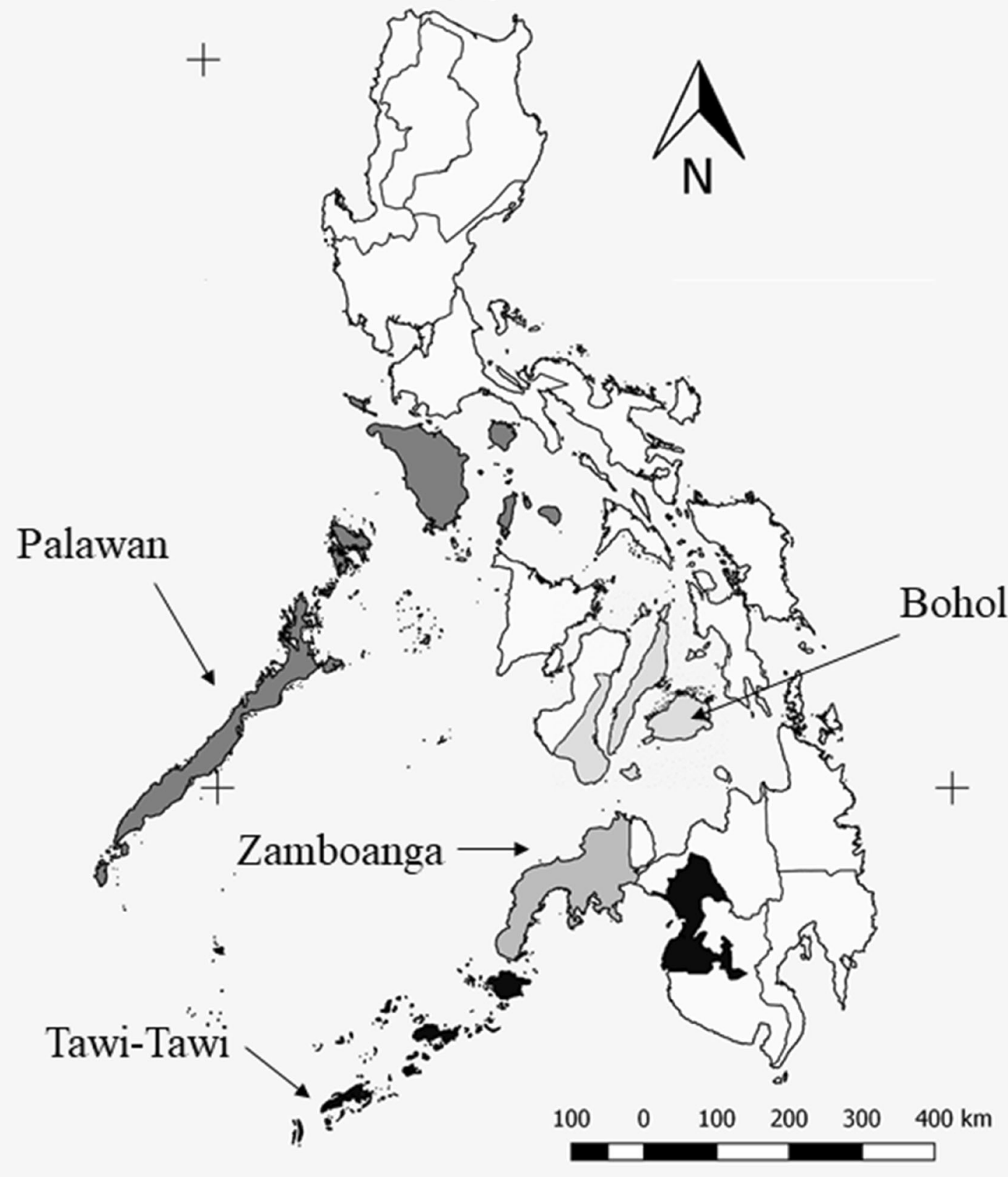

$\infty$

Projection and Datum: WGS84/UTM

Source: Fisheries Statistics of the Philippines 2017 Philippine Statistics Authority

Fig. 1 Map showing four main seaweed producing regions in the Philippines including Tawi-Tawi (Bangsamoro Autonomous Region of Muslim Mindanao - BARMM), Zamboanga (Zamboanga Peninsula—Region IX), Palawan (MiMaRoPa—Region IV-B) and Bohol (Central Visayas — Region VII) 
(moderately useful), 1 (not useful) and 0 (not sure). Practice responses were 2/0 (often), (1) seldom and (2/0) never depending on the question and for $(0)$ yes, (1) not always or (2) no or not applicable. Maximum score of subcategory, sub-category score, category score and overall final score were computed according to Jia et al. (2017):

1. Maximum score of sub - category $=$ sum of the highest score for each question obtainable by the farmer

2. Sub-category score $=\frac{\text { sum of original scores of each question }}{\text { maximum score of category }} \times 100$

3. Category score $=\frac{\text { sum of each subcategory score of category }}{\text { maxim category }} \times 100$

4. Overall final score $=\frac{\text { mum of each category score }}{\text { maximum score of categories }} \times 100$

The scores (\%) obtained from the KAP questionnaires were computed and defined as "Good" ( $\geq 75 \%)$, "Fair" (50-75\%) and "Poor" $(<50 \%)$ (Table 1). Categories were divided into two sub-categories: for the knowledge category, the subcategories included basic understanding and awareness, whilst external and internal biosecurity sub-categories were used for attitude and practice. For this analysis, external biosecurity pertained to stocking, equipment and disinfection, and the control of visitors to the farm, whilst internal biosecurity referred to detection, prevention and treatment of pathogenic agents.

One-way analysis of variance (ANOVA) was initially used to compare mean scores between regions using IBM SPSS Statistics 23. If a significant difference $(p=0.05)$ was detected, a further test was made to determine which specific regions were statistically different, comparing a pair at a time. The Tukey test was employed if variances were equal and the Games-Howell test if the variances were not equal. Results were expressed as mean \pm standard error of mean (SEM). A linear relationship between knowledge and attitude, attitude and practice and knowledge-based understanding and attitude were assessed using correlation analysis at $p=0.05$ significance level.

\section{Results}

\section{Demographics}

Sixty-five percent of the 120 seaweed farmers interviewed were men. Most of the farmers from the four regions were men, except in Bohol, where $61 \%$ of the farmers were female. The number of male farmers in Zamboanga was significantly lower $(p<0.05)$ than the number of males from Palawan and Bohol, but not compared with Tawi-Tawi (Fig. 2a). The majority of the farmers were in the range of 21-50 years in all four regions $(73 \%)$. Only one farmer was younger than 21 years, and $26 \%$ were more than 50 years. The ages in the four regions did not differ significantly (Fig. 2b). The farmers in Palawan were better educated than those from Zamboanga, but not compared with the farmers from Tawi-Tawi and Bohol. The educational attainment of farmers from Zamboanga, however, was not significantly different with the farmers from the Tawi-Tawi and Bohol regions. Unlike the other three regions, none of the farmers from Palawan graduated with less than a primary school (LPS) education and the remainder graduated from primary (PS) (25\%), secondary (SS) (50\%) and tertiary (TS) (25\%) level education. Overall, the highest number (30\%) of farmers interviewed was only primary school graduates. Nevertheless, there was no significant difference in the proportion of farmers that graduated at primary, secondary and tertiary education level with $24.25,22.55$ and 20.8\%, respectively (Fig. 2c).

The number of years a farmer spent on their farm did not significantly differ between regions, and overall, the majority of farmers interviewed spent more than 10 years involved in seaweed cultivation (73\%) (Fig. 2d). Most of the farmers $(72 \%)$ had received no formal training in seaweed farming (Fig. 2e). In Tawi-Tawi, only two farmers had been trained by the Bureau of Fisheries and Aquatic Resources (BFAR) and one had been trained by the Philippine Development
Table 1 Summary of the rating of knowledge, attitude and practice scores from the four main seaweed producing regions surveyed in the Philippines

\begin{tabular}{|c|c|c|c|c|c|c|}
\hline \multirow{2}{*}{$\begin{array}{l}\text { Biosecurity } \\
\text { category/ } \\
\text { subcategory }\end{array}$} & \multicolumn{2}{|l|}{ Knowledge } & \multicolumn{2}{|l|}{ Attitude } & \multicolumn{2}{|l|}{ Practice } \\
\hline & $\begin{array}{l}\text { Basic } \\
\text { understanding }\end{array}$ & Awareness & External & Internal & External & Internal \\
\hline \multirow[t]{2}{*}{ Tawi-Tawi } & Fair & & Good & & Fair & \\
\hline & Good & Fair & Good & Good & Fair & Fair \\
\hline \multirow[t]{2}{*}{ Palawan } & Fair & & Good & & Fair & \\
\hline & Good & Poor & Good & Good & Fair & Fair \\
\hline \multirow[t]{2}{*}{ Zamboanga } & Fair & & Good & & Fair & \\
\hline & Good & Poor & Fair & Good & Fair & Fair \\
\hline \multirow[t]{2}{*}{ Bohol } & Fair & & Good & & Fair & \\
\hline & Fair & Poor & Good & Good & Fair & Fair \\
\hline
\end{tabular}



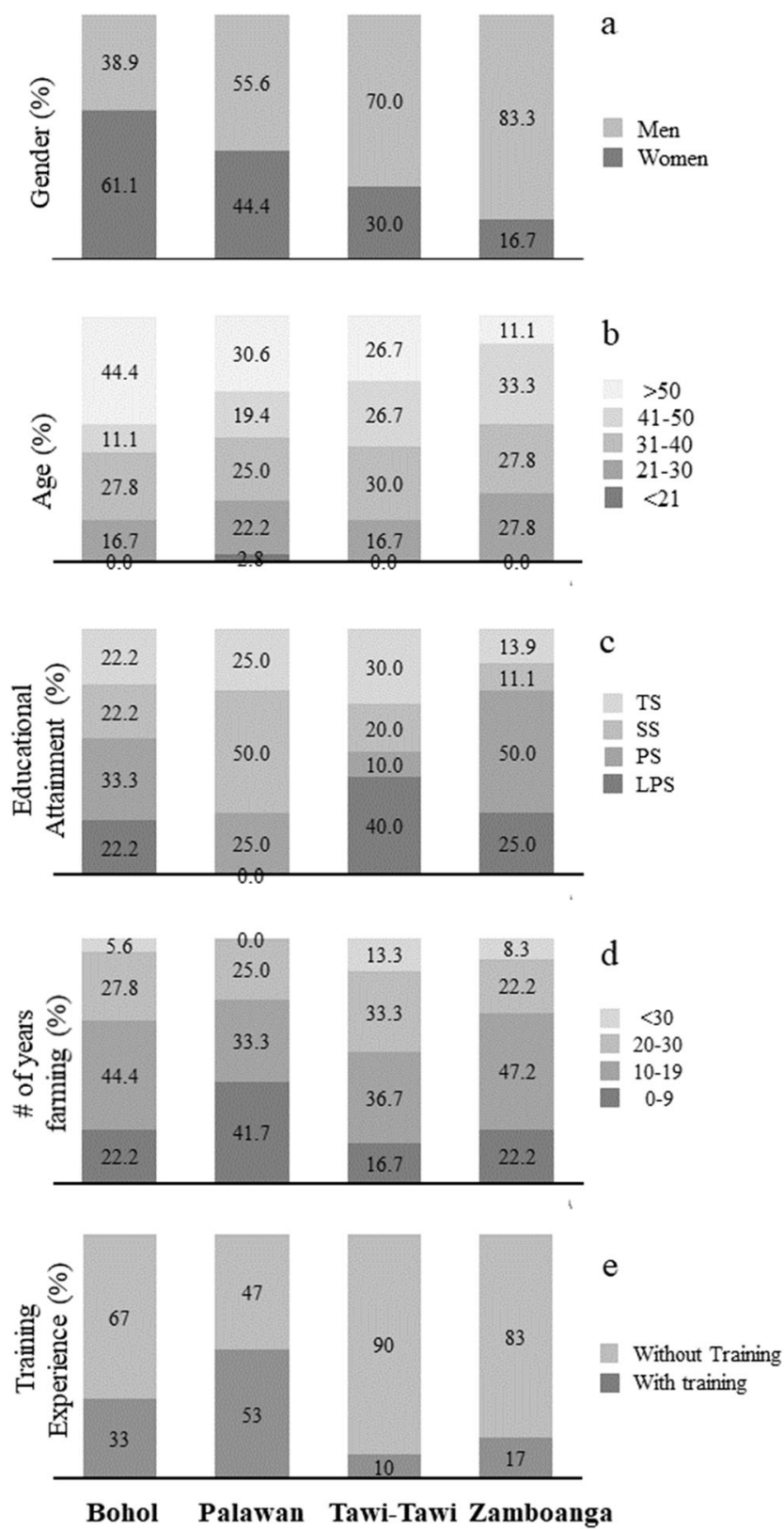

Fig. 2 Demographic percentages of $\mathbf{a}$ gender, $\mathbf{b}$ ages, $\mathbf{c}$ educational attainment (TS, tertiary school; SS, secondary school; PS, primary school; and LPS, less than primary school), d number of years in farming and e training experience of farmers from the top seaweed producing regions in the Philippines-Tawi-Tawi, Zamboanga, Palawan and Bohol

Assistance Program, Inc. (PDAP). In Zamboanga, three farmers had been trained by BFAR and three farmers by the Technical Education and Skills Development Authority (TESDA). In Palawan, 10 farmers were trained by BFAR, two farmers by BFAR and City Agriculture, five farmers by BFAR and Department of Social Welfare and Development (DSWD) and two farmers by the Western Philippines University (WPU) (Table 2).

\section{KAP analyses}

\section{Knowledge}

The mean scores for knowledge, based on the seaweed farmers understanding of pests and diseases and how they could spread to other farms differed significantly between regions. Farmers from Tawi-Tawi had a significantly higher knowledge compared with farmers from Palawan and Bohol $(p<0.05)$. Farmers from Zamboanga had knowledge mean scores, which were not significantly different from Tawi-Tawi and Palawan farmers' mean scores. Lastly, the knowledge mean scores of those farmers from Palawan did not differ significantly from the mean scores of farmers from Bohol $(p$ $<0.05$ ). Nevertheless, all the knowledge mean scores fell under the "Fair" category, with a range of scores from $53.3 \% \pm$ 2.0 to $67.6 \% \pm 2.7$ (Fig. 3a).

\section{Knowledge sub-categories}

For the sub-categories of knowledge, there was no significant difference between the basic understanding mean score of all the farmers, irrespective of region $(p>0.05)$. All farmers had a "Good" $(78.9 \% \pm 1.3-81.0 \% \pm 2.1)$ basic understanding of pests and diseases, with the exception of farmers from Bohol. These farmers were rated "Fair" $(73.8 \% \pm 1.7)$ based on their knowledge of the diseases that could affect their farms. However, under the awareness sub-category, only those farmers from Tawi-Tawi had a "Fair" score $(57.1 \% \pm 3.2)$, which was significantly different to the farmers from Zamboanga $(44.4 \% \pm 2.3)$, Palawan $(38.9 \% \pm 0.8)$ and Bohol $(34.7 \% \pm 2.8)$, who were rated as "Poor". The mean score of farmers from Zamboanga was significantly higher from the mean score of farmers from Bohol, whilst the mean score of Palawan farmers did not significantly differ from the mean scores of farmers from both Zamboanga and Bohol $(p<$ 0.05) (Fig. 3b, c).

\section{Attitude}

The mean score of farmers from Bohol $(81.9 \% \pm 5.16)$ was not significantly different from the mean scores of farmers from the three other regions. Mean attitude scores of farmers from Tawi-Tawi $(88.3 \% \pm 2.1)$, Palawan $(82.5 \% \pm 3.1)$ and Zamboanga $(75.3 \% \pm 4.2)$, however, differed significantly from each other $(p<0.05)$ (Fig. 4a). All mean attitude scores, irrespective of region, were rated as "Good".

\section{Attitude subcategories}

The external sub-category mean score of Tawi-Tawi farmers $(87.8 \% \pm 1.7)$ did not significantly differ from mean score of farmers from Palawan $(85.0 \% \pm 1.2)$. The Tawi- 
Table 2 Summary of local government units, non-government agencies, academes, and other institutions involved in seaweed farming assistance in Tawi-Tawi, Palawan, Zamboanga, and Bohol

\begin{tabular}{llll}
\hline Tawi-tawi & Palawan & Zamboanga & Bohol \\
\hline $\begin{array}{lll}\text { 1. Bureau of Fisheries and } \\
\text { Aquatic Resources (BFAR) }\end{array}$ & $\begin{array}{l}\text { 1. Bureau of Fisheries and Aquatic } \\
\text { Resources (BFAR) }\end{array}$ & $\begin{array}{l}\text { 1. Bureau of Fisheries and Aquatic } \\
\text { Resources (BFAR) }\end{array}$ & $\begin{array}{l}\text { 1. Bureau of Fisheries and } \\
\text { Aquatic Resources (BFAR) }\end{array}$ \\
$\begin{array}{ll}\text { 2. Philippine Development } \\
\text { Assistance Program, Inc. }\end{array}$ & $\begin{array}{l}\text { 2. Department of Social Welfare } \\
\text { and Development (DSWD) }\end{array}$ & $\begin{array}{l}\text { 2. Technical Education and } \\
\text { Skills Development Authority }\end{array}$ & \\
(PDAP) & 3. Western Philippines University & (TESDA) & \\
& (WPU) & & \\
\hline
\end{tabular}

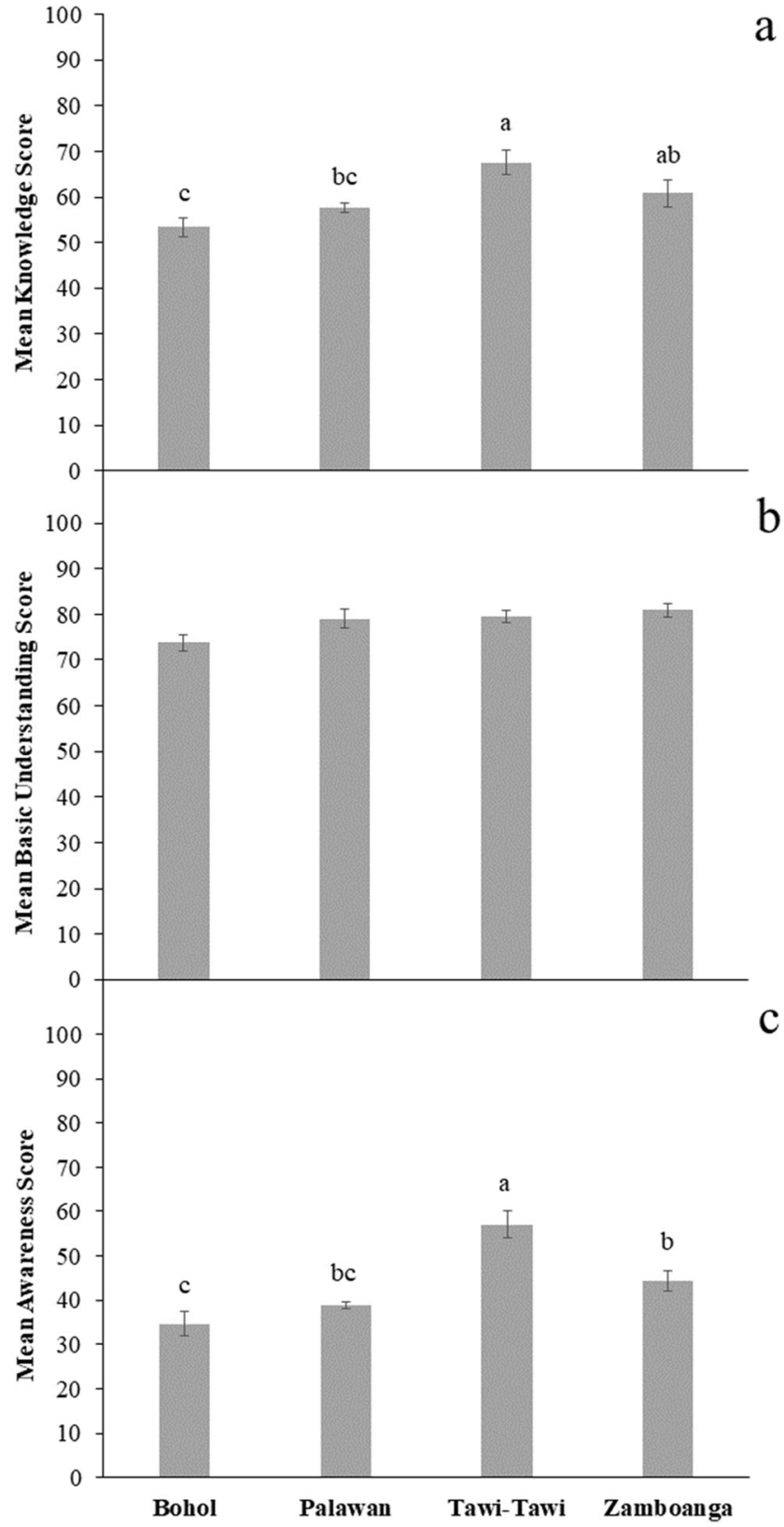

Fig. 3 Mean scores $( \pm$ SEM) of a knowledge and its subcategories, b basic understanding and $\mathbf{c}$ awareness of seaweed farmers pertinent to seaweed farming and biosecurity measures. Means with different letters are significantly different at $p<0.05$ a Tawi farmers' mean scores however, were significantly higher than the farmers' mean scores from Zamboanga $(71.7 \% \pm 3.1)$ and Bohol $(76.9 \% \pm 3.6)(p<0.05)$. Mean score of farmers from Palawan was significantly greater than from Zamboanga, but there was no significant difference with Bohol farmers (Fig. 4b). Internal sub-category mean score of Tawi-Tawi farmers $(88.6 \% \pm 1.4)$ was not significantly different from the Bohol farmers $(84.4 \% \pm$ 3.2) but was significantly higher than the farmers' mean scores from Palawan $(81.0 \% \pm 1.7)$ and Zamboanga $(76.8 \% \pm 1.7)$. The Bohol mean score had no significant difference with Palawan but was significantly greater $(p<$ $0.05)$ compared with the mean score of farmers from Zamboanga (Fig. 4c). All attitude subcategory scores were rated as "Good", with the exception of the external biosecurity score in Zamboanga, which was rated as "Fair".

\section{Practice}

The mean practice scores of farmers from Bohol $(66.2 \% \pm$ 5.3) and Palawan $(64.4 \% \pm 1.3)$ were significantly higher $(p$ $<0.05)$ compared with the mean score of farmers from Zamboanga $(54.5 \% \pm 2.9)$, but they were not significantly different with the mean score from Tawi-Tawi $(59.9 \% \pm 2.4)$ $(p<0.05)$. The practice mean scores of farmers from all regions were rated as "Fair" (Fig. 5a).

\section{Practice subcategories}

Under the external practice sub-category, mean scores of farmers from Bohol $(63.4 \% \pm 3.7)$ and Palawan $(61.3 \% \pm$ 1.4) were significantly higher $(p<0.05)$ compared with the mean score of farmers from Zamboanga $(54.5 \% \pm 1.5)$. There was no significant difference, however, with the mean score of farmers from Tawi-Tawi $(60.1 \% \pm 1.6)$, which were all rated "Fair" (Fig. 5b). The internal sub-category mean scores showed that there was a significant difference between mean score of farmers from Palawan $(70.7 \% \pm 1.9)$ compared with the mean scores of farmers from Tawi-Tawi $(59.6 \% \pm 2.6)$ and Zamboanga $(55.9 \% \pm 1.7)$, but not with farmers from Bohol $(68.4 \% \pm 3.2)$. The mean score of farmers from Tawi-Tawi 


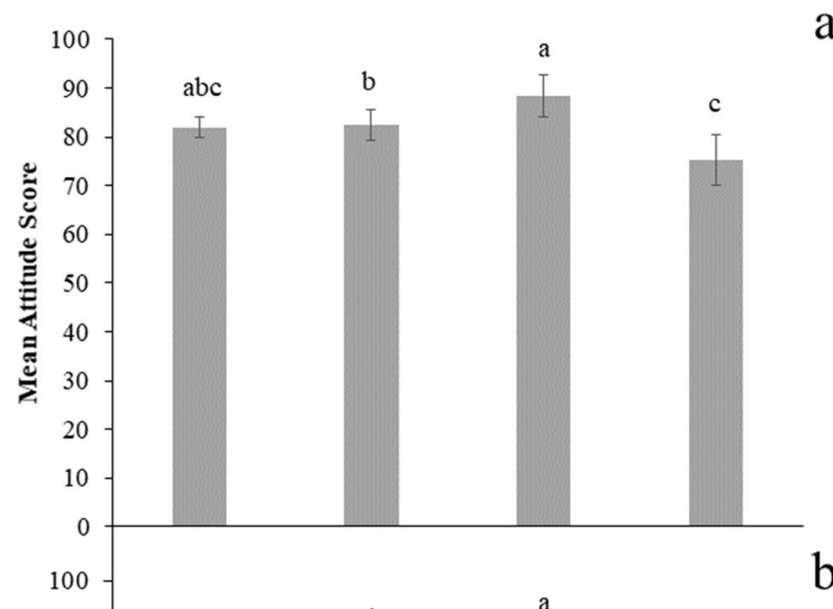

a

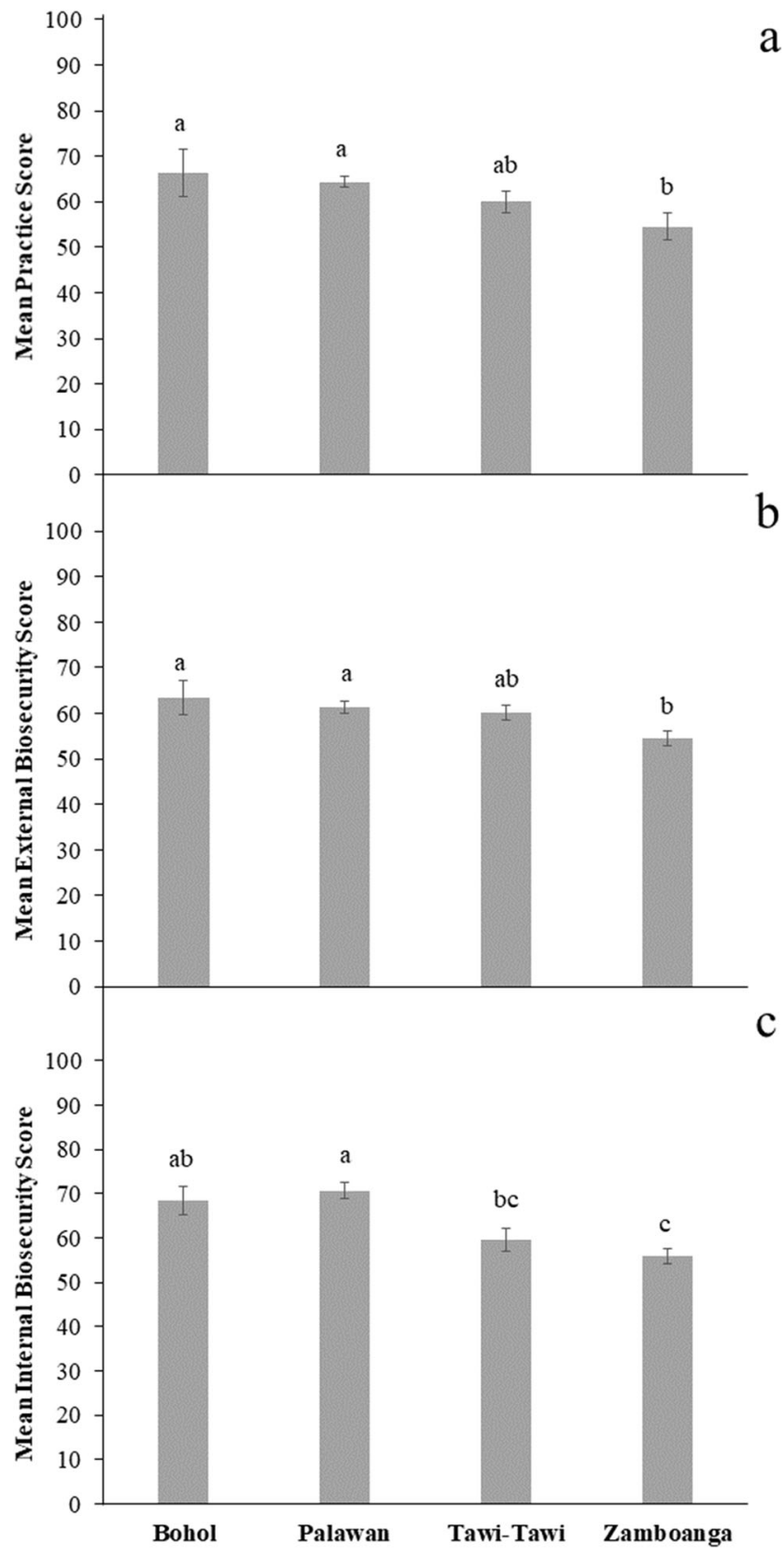

Fig. 5 Mean scores ( \pm SEM) of a practice and its subcategories, b external and $\mathbf{c}$ internal biosecurity of seaweed farmers pertinent to seaweed farming and biosecurity measures. Means with different letters are significantly different at $p<0.05$

\section{Discussion}

from Bohol. All internal biosecurity scores were rated as "Fair" (Fig. 5c).

Based on the mean scores of the three categories, knowledge was rated "Fair", attitude "Good" and practice "Fair" in all sites (Table 1). Positive correlations between knowledge and attitude scores (Fig. 6), and attitude and practice scores were observed (Fig. 7). However, correlation between knowledge and practice scores (Fig. 8) was negatively correlated. Nevertheless, these correlations are weak $(R<0.6)$.

\section{Demographics}

The majority of farmers from the top producing regions in the Philippines were male, with the exception of Bohol. The seaweed farming technique, religion and survey timing are possible explanations for this gender imbalance. For example, in Tawi-Tawi, Zamboanga and Palawan farmers use deep-sea farming techniques, since the seaweed is usually grown in 


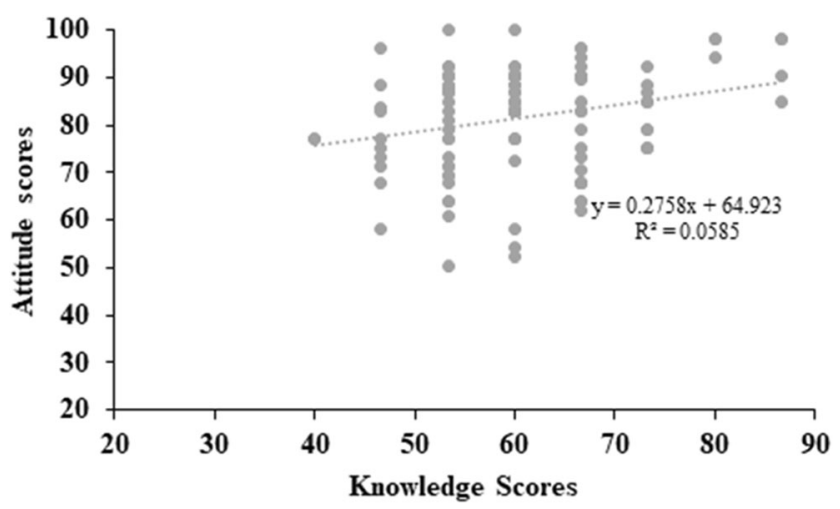

Fig. 6 Linear relationship between knowledge and attitude scores of seaweed farmers in the top four producing regions in the Philippines

water depths greater than $4 \mathrm{~m}$. These techniques include the hanging long-line and multiple raft, long-line techniques, which require intensive labour, plus boat handling and freediving skills to install and maintain the supporting structures (Hurtado et al. 2014). These skills are typically acquired by the male farmers. In contrast, $61 \%$ of farmers were female in Bohol, where the fixed-off bottom farming technique is widely used in shallow, coastal waters. This type of farming technique does not require the use of boats or free diving and can be done during low tide. Similarly, in Tanzania, fixed-off bottom is used in seaweed culture and the farms are predominantly operated by female farmers (Msuya and Hurtado 2017). In Tawi-Tawi and Zamboanga, in particular, religion may also be a factor in influencing the gender of the farmers, with the former region being almost $100 \%$ Muslim, whilst the latter contains many Muslim migrants from the Sulu archipelago, located to the south of the region. Muslim regions have a strong belief that males should be employed in physically demanding jobs, whereas in the Christian-majority regions of northern Palawan and Bohol, both male and female farmers are accepted by the industry. The timing of the surveys may also have influenced the scores, as the farmers were interviewed according to their availability. During the survey,

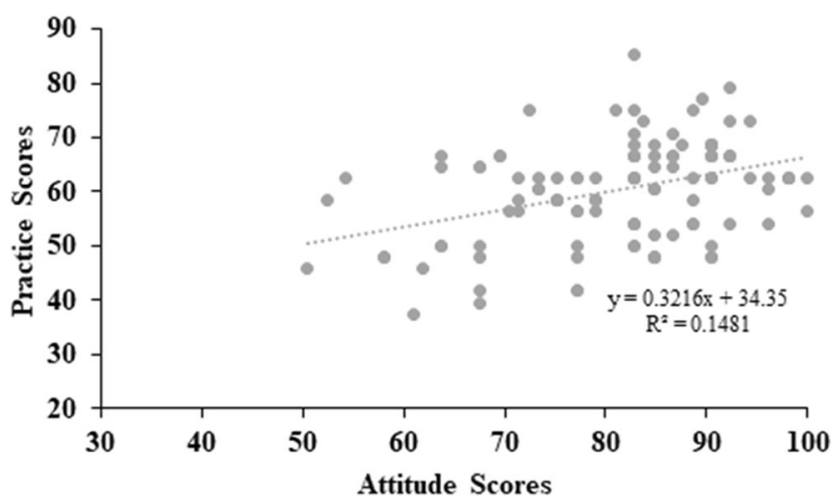

Fig. 7 Linear relationship between attitude and practice scores of seaweed farmers in the top four producing regions in the Philippines it was noted that some male farmers in Bohol and Palawan had different occupations during the day and did not solely work on the seaweed farms, whereas the female farmers who were surveyed were typically preparing the seaweed for planting out or for post-harvest drying and so were available to answer the survey questions. Though there were reports that male farmers are given more opportunities in seaweed farming than female farmers (Suyo et al. 2020), every effort was taken to minimize gender and religious bias in the survey methodology.

The range in farmers' age was very similar in all regions (18-73 years). An almost equal proportion between old ( $>40$ years) and young ( $<40$ years) seaweed farmers was observed. The absence of any difference of farmers' ages in different regions suggests that the knowledge of seaweed farming is typically passed down through the generations in the Philippines. This is supported by the length of farming experience recorded in the survey. No significant difference was found in the length of farming experience between the different regions. Palawan has the most (41.7\%) number of farmers who had $0-10$ years of farming experience. The majority of farmers in the regions surveyed, however, had been in the industry since their youth, and the skills and knowledge were passed from one generation to the next.

Over $75 \%$ of the farmers interviewed did not finish tertiary education and $51 \%$ had only undergone primary education. Considering the archipelagic nature of the Philippines, which is composed of many islets, access to education is difficult. Many farmers live in small communities, consisting of nuclear and extended families, whose stilt houses are in the middle of the sea near their farms (otherwise known as "pondohans"), primary and secondary education is lacking in these areas, except for a few day care centres for children 3-5 years of age. Palawan farmers, however, were found to have a significantly higher overall education attainment compared with Zamboanga, but insignificantly different from Tawi-Tawi and Bohol. This may be the result of education provision in these areas, for example, Palawan has many universities, such

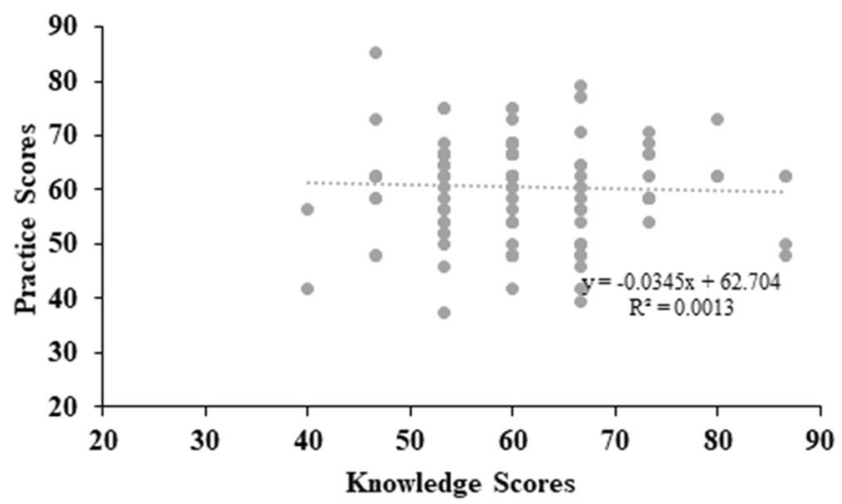

Fig. 8 Linear relationship between knowledge and practice scores of seaweed farmers in the top four producing regions in the Philippines 
as the Western Philippines University (WPU), Palawan State University (PSU) and other colleges. There are a number of national secondary schools (e.g. Sipangkot, Sitangkai), together with the Mindanao State University College of Technology and Oceanography (MSU-CTO) in Tawi-Tawi. Bohol and neighbouring islands (e.g. Cebu and Leyte) also are supported with several secondary schools, which could provide education to the seaweed farmers. The lower education of seaweed farmers, however, in Zamboanga compared with the other regions may not be directly related to education access, since several secondary and tertiary schools are located in close proximity, but due to political instability. Since the early 1990s, this region has been destabilized through terrorist acts (Manalo 2004), some of which burnt education establishments, thus interrupting the education of many children.

Training in seaweed farming practices, however, is important in assisting farm productivity. Palawan, however, was the only region surveyed, where more than half of the interviewed farmers had received training. In this region, access to training centres is relatively straight-forward and the local government is responsible for providing training to the seaweed farmers (Lacanilao 2015), enabling them to diversify their existing livelihoods (i.e. fishing) and to provide additional income. In contrast, in Tawi-Tawi only $10 \%$ of the farmers have had formal government-led training. It is interesting to note that mostly of the seaweed farmers in this region, especially in Sitangkai live in the "pondohans", where it is expected that all members of the household, including the young ones, are trained by the older family members to do the rudiments of seaweed farming, such as planting out the seedlings (Suyo et al. 2020). It is by observation and personal experience that they gain knowledge in seaweed farming in these areas. Seaweed production could, therefore, not be correlated with the level of education and whether training had been undertaken. However, engagement between farmers and scientists for science-based education, trainings and professional development should be encouraged (Hueston 2017), especially when new technologies or innovations are introduced. Government assistance is also essential in improving any communities' living standards (Sherman et al. 2013; Kakwani and Son 2016; Barrientos 2019).

\section{KAP analyses}

This KAP study on seaweed farming in the Philippines is the first of its kind. Farmers' knowledge on seaweed diseases was found to be "good", which is unsurprising since the farmers and their families are involved in the industry from a young age and their knowledge of pests (e.g. green or red filamentous algae) and disease (e.g. "ice-ice") is typically passed down through the generations. The farmers are also highly aware of the seasonal occurrence of epiphytes, "ice-ice" disease and grazers (e.g. rabbitfish and parrotfish) on their farms, particularly when there is a change in the direction of the trade winds. The farmers, however, were not aware of parasites and invasive species, even though a considerable body of knowledge exists regarding the economic and environmental threats from invasive species, including Kappaphycus (Wittenberg and Cock 2001) and how to manage their introductions (Cook et al. 2016). As there is no specific biosecurity guidance for seaweed cultivation and as Kappaphycus species are indigenous in the Philippines (Doty 1973, 1985, 1987), it is not surprising that seaweed farmers do not consider invasive species to be a threat to the industry. In addition, the farmers have a poor awareness of the potential introduction pathways for pests and diseases, which is a possible reason for the lack of preventative biosecurity measures employed on the farms.

Farmers' biosecurity-related practices were rated "fair". The monitoring of new crops and the disinfection of culture materials and equipment scored the highest. Farmers tended to visit their farms regularly ( $\sim 3$ times per week) for general husbandry and maintenance, which included shaking debris from the culture lines that inhibited seaweed growth. Macroepiphytes are typically removed and disposed of on land, which is a practice encouraged for many marine invasive species (Cook et al. 2016). Post-harvest, farmers generally disinfected their culture lines by sun drying the equipment for 2-3 days. Culture lines are also visually inspected before new seedlings are attached. Certain equipment, however, such as main lines, stakes and anchors can be left continuously in the water and not cleaned for up to three years. This is particularly the case, with the multiple raft-long line system, as the farmers are financially unable to replace and or remove from the water and clean all the equipment after each harvest, thus leaving a potential reservoir of diseased algae and pests in the water, which can infect the new crop. In other aquatic farming industries, it is common to have a regular fallowing period to prevent the cross contamination of successive crops (Bron et al. 1993; Werkman et al. 2011; Alvial et al. 2012; Damodaran et al. 2019). Similarly, some seaweed farmers will move their farms to a different area, if space is available, and try to obtain new healthy seedlings from another region.

The farmers are also not accustomed and/ or trained to make any measurements of water quality, unlike those regularly made in closed pond systems (Boyd and Tucker 2012) or in shrimp culture, for example (Felix 2009). Although the monitoring of water quality is not an assurance to prevent disease and pest outbreaks, it can provide an early warning to the farmers, as to the likelihood of an impact on production (Crawford and MacLeod 2009) and could verify the effects of good aquaculture practices (Boyd 2009). The farmers, however, do closely monitor their crops and will either quickly remove diseased and/ or pest infected seaweed from their farm or harvest the crop early. Similarly, the early harvesting of the crop is used as an essential biosecurity measure to avoid the spread of diseases in shrimp (Lotz 1997) and finfish 
aquaculture (Bartlett 2017; Qviller et al. 2020). Some farmers $(<10 \%$ interviewed) will treat their seeds with inorganic fertilizers (e.g. urea) to increase the resistance to disease when the first signs of disease appear. Studies using seaweed extract bio-stimulants (Borlongan et al. 2011; Hurtado et al. 2012; Ali et al. 2018, 2020) and inorganic fertilizers (Luhan et al. 2015) have shown good growth of Kappaphycus after enrichment. Similar encouraging results were reported when using a seaweed bio-stimulant in Saccharina japonica (Umanzor et al. 2019) and Gracilaria fisheri (Chirapart et al. 2019). However, farmers in the Philippines are banned from using any chemical or inorganic fertilizers (LGU (Local government Unit) 2018) without any scientific references negating the results aforementioned. Notwithstanding, reports by Ali et al. (2018, 2020) claimed that Kappaphycus alvarezii and K. striatus, when pre-treated with seaweed extract bio-stimulant prior to out-planting in the sea, showed higher carrageenan yield, viscosity and gel strength compared with the untreated ones. The additional of bio-stimulants, therefore, may be effective in managing the crops efficiently for a better carrageenan quality, although further investigation on their efficacy will have to be performed at a commercial scale, in cooperation with the farmers.

The seaweed farmers will also regularly share equipment and culture lines with other farmers, thus providing the opportunity for the inter-farm spread of pests and disease. This pathway has been implicated in the spread of aquatic diseases (e.g. infectious salmon anaemia (Alvial et al. 2012), shrimp WSSV (Walker and Mohan 2009)) and many aquaculture industries have introduced strict restrictions on the sharing of equipment between farm sites as a key biosecurity measure to minimize the spread of disease (Karreman 2006; Alvial et al. 2012). The interconnected nature of the marine environment and the seaweed farms, however, also means that pests and disease can spread naturally through the water column or via human-mediated means, such as on the hulls of the farm work boats. Previous studies have found that epiphytes can be spread between farms when attached to these boats (de Castro et al. 2017; Holbech and Pedersen 2018); however, the seaweed farmers were unaware that this could lead to the spread of pests. In addition, introducing new seedlings from other regions and mixing them with the existing crops was not seen by the farmers as a high risk activity. Farmers routinely keep crops from different sources in one area. In contrast, the salmon aquaculture industry in Chile has adopted an "all in all out" regulation to reduce the spread of infectious salmon anaemia and the mixing of different year classes is not allowed (Alvial et al. 2012).

The farmers typically make a visual check of the seaweeds' health status before payment occurs; however, this may not be sufficient to identify the microscopic stages of many epiphytes, particularly those that inhabit the internal structure of the thallus of $K$. alvarezii (Vairappan et al. 2008) and
Gracilaria chilensis (Leonardi et al. 2006). Again, numerous invasive species have been unintentionally introduced alongside species purchased for stocking purposes and rigorous measures (e.g. quarantine and specific-pathogen free varieties (SPF)) have been developed to control this pathway of introduction. In crustaceans, SPF broodstock development was the initial solution (Hastein et al. 2008) to avoid disease introduction from wild populations. Pathogen-free cultivars, broodstock or seedstock has also been found to be important, after disinfection of the culture area, in aquaculture (Baldock et al. 2006) and in plant crops (Gamliel and Fletcher 2017). In addition, the seaweed farmers do not keep records of crop loss, as this is seen as non-essential additional work and reporting disease and/or pest outbreaks in the Philippines is not practiced. In catfish aquaculture in China, Jia et al. (2017) also reported that although companies recommended recording pest and disease outbreaks, farmers did not typically comply. Interestingly, the majority of seaweed farmers in this study did state that it could be important to the biosecurity of the farm to record water quality and crop losses. The reporting of outbreaks on aquaculture sites has been introduced in many countries as a means of monitoring and controlling the spread of pests and disease (in the USA at aphis. usda.gov; Australia at outbreak.gov.au; and the UK at www. gov.uk). Even Asia has a reporting system which was developed in 1996 through the recommendations of the Network of Aquaculture Centres of Asia-Pacific (NACA)/ World Organization for Animal Health (OIE). Subasinghe et al. (2003) stated that better systems in reporting aquatic diseases should be given importance, which is seconded by Leung and Bates (2013). In the risk management framework for plant biosecurity, reporting was also stated as one of the most important processes in risk management to coordinate next steps for a complete eradication of sighted pests (Gamliel et al. 2017). This has been particularly effective in the case of disease outbreaks in the Pyropia cultivation industry in the Republic of South Korea, at raising awareness and increasing government funding for further research into the diseasecausing agents and potential control mechanisms (CottierCook et al. 2016).

Fortunately, farmers' attitude scores towards biosecurity were "Good" (> 75\%), which indicates the willingness of farmers to change their present practices, such as recordings of crop loss and water quality. In catfish aquaculture in China, it was reported that farmers have fair attitudes, in contrast to their poor practices (Jia et al. 2017). This also indicated that there is room for improvement on farmer's practices. Other studies have proven that training can improve practices of farmers, for example in antimicrobial usage and resistance in livestock and aquaculture (Pham-Duc et al. 2019), in backyard poultry (Conan et al. 2013), cattle farming (Brennan and Christley 2013) or even in the usage of personal protective equipment when using pesticides (Matthews 2008). The 
"Fair" score of the farmers' practices, however, in all the regions clearly suggests that their practices can still be improved. This improvement could be achieved through the addition of scientifically proven biosecurity practices for farm and crop management and disease prevention to the existing training programmes run, by BFAR, etc., and to existing seaweed manuals (Hurtado and Agbayani 2000; Hurtado et al. 2008a, b, c; Arevalo et al. 2012). The farmers, however, were against any government control over seedling quality, unlike in Korea and China, where there are state-run seedling nurseries (Zhang 2018; Hwang and Park 2020). In addition, the farmers were not routinely reporting their production, even though the Department of Agriculture-Bureau of Fisheries and Aquatic Resources (DA-BFAR) Fisheries Administrative Order (FAO) No. 108 "Regulations governing the gathering and farming of seaweeds" states that a license holder shall record harvested and cultured seaweed (Department of Agriculture - Bureau of Fisheries and Aquatic Resources (DA-BFAR) 1973). This could, however, be a mechanism to enable farmers to report their crop losses, as a result of pest and disease outbreaks and enable the Philippine government to gain a more accurate record of how introduced biosecurity measures have increased national seaweed production.

\section{Conclusion}

The biosecurity KAP survey has been essential in identifying the gaps in the knowledge, attitude and practice of seaweed farmers toward pest and disease outbreaks in the Philippines, and the results provide robust evidence, which can be used in policy development. Mathiesen (2019) claimed, in order to create a healthy and resilient host, a combination of better health, genetics, nutrition (in this case, nutrient enrichment) and good governance are needed for a maturing aquaculture industry where the seaweed industry could be a very good example. This study has highlighted the willingness of the seaweed farmers' to minimise the introduction and spread of pests and disease. The accessibility to new information related to biosecurity practices, provided at a level which can be readily understood, could be significantly improved in certain regions. This study also emphasizes some differences between practices in a close system, i.e. shrimp culture in closed ponds compared with seaweed farming, in a more open system, and how the biosecurity measures have to be carefully tailored to the cultivation system and surrounding environment. It has also highlighted the fact that the existing training material and relevant policies require updating to included biosecurity-related recommendations and that the frequency of the training programmes should be increased, both to share information and to build trust between the trainers and the farmers. As without the farmers providing reliable information to the national agencies, the true cost and extent of the outbreaks will always be under-represented and the problem will never be fully addressed.

Acknowledgements The researchers would like to thank all the farmers who willingly participated in all interviews and all the LGUs who helped throughout the logistics. This study was also made easier by field guides and translators from all sites.

Funding This study was supported by the UK Research and Innovation-Global Challenges Research Fund (UKRI-GCRF) “GlobalSeaweedSTAR” Programme (Grant No. BB/P027806/1).

Open Access This article is licensed under a Creative Commons Attribution 4.0 International License, which permits use, sharing, adaptation, distribution and reproduction in any medium or format, as long as you give appropriate credit to the original author(s) and the source, provide a link to the Creative Commons licence, and indicate if changes were made. The images or other third party material in this article are included in the article's Creative Commons licence, unless indicated otherwise in a credit line to the material. If material is not included in the article's Creative Commons licence and your intended use is not permitted by statutory regulation or exceeds the permitted use, you will need to obtain permission directly from the copyright holder. To view a copy of this licence, visit http://creativecommons.org/licenses/by/4.0/.

\section{References}

Ali MKM, Yasir SM, Critchley AT, Hurtado AQ (2018) Impacts of Ascophyllum marine plant extract powder (AMPEP) on the growth, incidence of the endophyte Neosiphonia apiculata and associated carrageenan quality of three commercial cultivars of Kappaphycus. J Appl Phycol 30:1185-1195

Ali MK, Critchley AT, Hurtado AQ (2020) The impacts of AMPEP K ${ }^{+}$ (Ascophyllum marine plant extract, enhanced with potassium) on the growth rate, carrageenan quality, and percentage incidence of the damaging epiphyte Neosiphonia apiculata on four strains of the commercially important carrageenophyte Kappaphycus, as developed by micropropagation techniques. J Appl Phycol 32:1907-1916

Alvial A, Kibenge F, Forster J, Burgos JM, Ibarra R, St-Hilaire S (2012) The recovery of the Chilean salmon industry. The ISA crisis and its consequences and lessons. Study for the Global Aquaculture Alliance co-sponsored by the World Bank, the Undersecretariat of Fisheries-Chile and the Chilean Salmon Industry Association (SalmonChile). Puerto Montt, Chile. 83pp

Amiri FB, Doosti-Irani A, Sedaghat A, Fahimfar N, Mostafavi E (2018) Knowledge, attitude, and practices regarding HIV and TB among homeless people in Tehran, Iran. Int J Health Policy Manag 7:549555

Arbiol J, Orencio PM, Nomura H, Takahashi Y, Yabe M (2016) Knowledge, attitude and practices towards leptospirosis among lakeshore communities of Calamba and Los Baños, Laguna, Philippines. Agriculture 6:18

Arevalo NB, Donaire TC, Ricohermoso MA, Simbajon R (2012) Better management practices for seaweed farming (Eucheuma and Kappaphycus). Network of Aquaculture Centres in Asia-Pacific (NACA), 21pp

Arif S, Thomson PC, Hernandez-Jover M, McGill DM, Warriach HM, Heller J (2017) Knowledge, attitudes and practices (KAP) relating to brucellosis in smallholder dairy farmers in two provinces in Pakistan. PLoS One 12:e173365 
Ask EI, Batibasaga A, Zertuche-González JA, de San M M (2003) Three decades of Kappaphycus alvarezii (Rhodophyta) introduction to non-endemic locations. In: Chapman ARO, Anderson RJ, Vreeland VI, Davidson IR (eds) Proceedings of the 17th International Seaweed Symposium. Oxford University Press, Oxford, pp 49-57

Baldock FC, Cameron AR, Perkins NR (2006) Aquatic animal health surveillance. In: Scarfe AD, Lee CS, O’Bryen PJ (eds) Aquaculture biosecurity: prevention, control, and eradication of aquatic animal disease. Blackwell Publishing, Iowa, pp 129-148

Barrientos A (2019) The role of social assistance in reducing poverty and inequality in Asia and the Pacific. Asian Deveopment Bank, Philippines. 30pp

Bartlett C (2017) Maine infectious salmon anemia virus control program standards. Maine Sea Grant Publications, Maine, USA. 132. 47pp. https://digitalcommons.library.umaine.edu/seagrant_pub/ 132 Accessed on 10 August 2020

Borlongan IAG, Tibubos KR, Yunque DAT, Hurtado AQ, Critchley AT (2011) Impact of AMPEP on the growth and occurrence of epiphytic Neosiphonia infestation on two varieties of commercially cultivated Kappaphycus alvarezii grown at different depths in the Philippines. J Appl Phycol 23:615-621

Boyd CE (2009) Better management practices for marine shrimp aquaculture. In: Tucker CS, Hargreaves JA (eds) Environmental best management practices for aquaculture. Wiley, New York, pp 227 260

Boyd CE, Tucker CS (2012) Pond aquaculture water quality management. Springer, New York, $\mathrm{p} 700$

Brennan ML, Christley RM (2013) Cattle producers' perceptions of biosecurity. BMC Vet Res 9:71

Bron JE, Sommerville C, Wootten R, Rae GH (1993) Fallowing of marine Atlantic salmon, Salmo salar L., farms as a method for the control of sea lice, Lepeophtheirus salmonis. J Fish Dis 16:487-493

Campbell I, Kambey C, Mateo J, Rusekwa SB, Hurtado A, Msuya F, Stentiford GD, Cottier-Cook EJ (2020) Biosecurity policy and legislation for the global seaweed aquaculture industry. J Appl Phycol 32:2133-2146

Chirapart A, Khreauthong S, Praiboon J, Rattanasaensri S (2019) Growth and epiphytic responses of Gracilaria fisheri to the seaweed extract under controlled-culture conditions. Paper presented at the 23rd International Seaweed Symposium, 28 April - 3 May 2019, Jeju, Korea (Abstract only)

Conan A, Goutard FL, Holl D, Ra S, Ponsich A, Tarantola A, Sorn S, Vong S (2013) Cluster randomised trial of the impact of biosecurity measures on poultry health in backyard flocks. Vet J 198:649-655

Cook EJ, Payne RD, MacLeod A, Brown SF (2016) Marine biosecurity: protecting indigenous marine species. Res Rep Biodivers Stud 5:114

Cottier-Cook EJ, Nagabhatla N, Badis Y, Campbell M, Chopin T, Dai W, Fang J, He P, Hewitt C, Kim GH, Huo Y, Jiang Z, Kema G, Li X, Liu F, Liu H, Liu Y, Lu Q, Luo Q, Mao Y, Msuya FE, Rebours C, Shen H, Stentiford G, Yarish C, Wu H, Yang X, Zhang J, Zhou Y, Gachon CMM (2016) Safeguarding the future of the global seaweed aquaculture industry. United Nations University (INWEH) and Scottish Association for Marine Science Policy Brief. 12pp

Crawford C, Macleod C (2009) Predicting and assessing the environmental impact of aquaculture. In: Burnell G, Allan G (eds) New technologies in aquaculture: improving production efficiency, quality and environmental management. CRC Press, Boca Raton, pp 679700

Damodaran D, Mojjada SK, Vase VK, Sukhdhane K, Abdul Azeez P, Kumar R (2019) Intercropping of marine finfish in shrimp ponds: A maiden feasibility study. PLoS One 14:e0216648

de Castro MCT, Fileman TW, Hall-Spencer JM (2017) Invasive species in the Northeastern and Southwestern Atlantic Ocean: A review. Mar Pollut Bull 116:41-47
Department of Agriculture - Bureau of Fisheries and Aquatic Resources (DA-BFAR) (1973) Fisheries Administrative Order (FAO) No. 108. Regulations governing the gathering and farming of seaweeds. https://www.bfar.da.gov.ph/LAW?fi=225 Accessed 16 Apr 2020

Doty MS (1973) Farming the red seaweed, Eucheuma, for carrageenans. Micronesia 9:59-73

Doty MS (1985) Eucheuma alvarezii, sp. nov. (Gigartinales, Rhodophyta) from Malaysia. In: Abbott LA, Norris JN (eds) Taxonomy of economic seaweeds: with reference to some Pacific and Caribbean species. California Sea Grant College Program. Rep. T-CSGCP-011, La Jolla, California, 37-45

Doty MS (1987) The production and use of Eucheuma. In: Doty MA, Caddy JF, Santalices B (eds) Case studies of seven commercial seaweed resources, vol 281. FAO Fisheries Technical Paper, pp $123-161$

Felix S (2009) Advances in shrimp aquaculture management. Daya Publishing House, New Delhi, India 95pp

Food and Agriculture Organization (2019) Committee on Fisheries (10th session): preventing and managing aquatic animal disease risks in aquaculture through a progressive management pathway. Trondheim. $11 \mathrm{pp}$

Gamliel A, Fletcher J (2017) Containment and eradication of invasive pathogens. In: Gullino ML, Stack JP, Fletcher J, Mumford JD (eds) Practical Tools for Plant and Food Biosecurity. Springer, Cham, pp 243-256

Gamliel A, Stack JP, Mumford JD (2017) A risk management framework for plant biosecurity. In: Gullino ML, Stack JP, Fletcher J, Mumford JD (eds) Practical tools for plant and food biosecurity. Springer, Cham, pp 97-119

Hardy-Smith P, Humphrey J, O'Connor W, Dove M, Barlow C (2019) Project Vietnamese molluscan biosecurity and veterinary diagnostic capacity. ACIAR, Canberra, Australia. 49pp

Hastein T, Binde M, Hine M, Johnsen S, Lillehaug A, Olesen NJ, Purvis N, Scarfe AD, Wright B (2008) National biosecurity approaches, plans and programmes in response to diseases in farmed aquatic animals: evolution, effectiveness and the way forward. Rev Sci Tech Off Int Epiz 27:125-145

Hayashi L, Reis RP, dos Santos AA, Castelar B, Robledo D, de Vega GB, Msuya FE, Eswaran K, Yasir SM, Ali MKM, Hurtado A (2017) The cultivation of Kappaphycus and Eucheuma in tropical and subtropical waters. In: Hurtado AQ, Critchley AT, Neish IC (eds) Tropical seaweed farming trends, problems and opportunities. Springer, Cham, pp 55-90

Holbech H, Pedersen KL (2018) Ballast water and invasive species in the Arctic. In: Vestergaard N, Kaiser BA, Fernandez L, Larsen JN (eds) Arctic marine resource governance and development. Springer, Cham, pp 115-137

https://zamboanga.com/z/index.php?title =2, 810_fishermen_in_Palawan_benefit_from_seaweed_farming_project $\bar{A}$ ccessed $1 \overline{5}$ Apr 2020

Hueston WD (2017) Engaging scientists and veterinarians in strengthening biosecurity systems. Rev Sci Tech Off Int Epiz 36:681-690

Hurtado AQ (2013) Social and economic dimensions of carrageenan seaweed farming in the Philippines. In: Valderrama D, Cai J, Hishamunda N, Ridler N (eds) Social and economic dimensions of carrageenan seaweed farming. Fish Aquaculture Tech Paper No. 580. FAO, Rome, pp 87-111

Hurtado AQ, Agbayani RF (2000) The farming of the seaweed Kappaphycus. Extension Manual No.32. SEAFDEC/AQD Tigbauan, Iloilo. 25pp

Hurtado AQ, Critchley AT, Bleicher-L'honneur G (2008a) Kappaphycus 'cottonii' farming. (revised edition), Makinaugalingon Printer \& Bookbinder. Iloilo City, Iloilo, Philippines 26pp

Hurtado AQ, Pactoran JE, Allaga AT, Faburada ES (2008b) Mga Dapat Alamin sa Pagsasaka ng Kappaphycus 'cottonii'. Philippine Development Assistance Program, Quezon City 38pp 
Hurtado AQ, Pactoran JE, Allaga AT, Faburada ES (2008c) Mga patut hatihun tungud pa pagtanum agal-agal atawa in pag-iyanum. Philippine Development Assistance Program, Quezon City 38pp

Hurtado AQ, Joe M, Sanares RC, Fan D, Prithiviraj B, Critchley AT (2012) Investigation of the application of Acadian Marine Plant Extract Powder (AMPEP) to enhance the growth, phenolic content, free radical scavenging, and iron chelating activities of Kappaphycus Doty (Solieriaceae, Gigartinales, Rhodophyta). J Appl Phycol 24:601-611

Hurtado AQ, Gerung GS, Yasir S, Critchley AT (2014) Cultivation of tropical red seaweeds in the BIMP-EAGA region. J Appl Phycol 26: 702-718

Hwang EK, Park CS (2020) Seaweed cultivation and utilization of Korea. Algae 35:107-121

Jia B, St-Hilaire S, Singh K, Gardner IA (2017) Biosecurity knowledge, attitudes and practices of farmers culturing yellow catfish (Pelteobagrus fulvidraco) in Guangdong and Zhejiang provinces, China. Aquaculture 471:146-156

Kakwani N, Son HH (2016) Social rate of return: a new tool for evaluating social programs. In: Kakwani N, Son HH (eds) Social welfare functions and development. Palgrave Macmillan, London, pp 295336

Kambey CSB, Campbell I, Sondak CFA, Nor ARM, Lim PE, CottierCook EJ (2020) An analysis of the current status and future of biosecurity frameworks for the Indonesian seaweed industry. J Appl Phycol 32:2147-2160

Karreman GA (2006) Elements of an aquatic animal health programinfectious hematopoietic necrosis in farmed Atlantic salmon in British Columbia. In: Scarfe AD, Lee CS, O'Bryen PJ (eds) Aquaculture biosecurity: prevention, control, and eradication of aquatic animal disease. Blackwell Publishing, Iowa, pp 155-163

Lacanilao M (2015) 2,810 fishermen in Palawan benefit from seaweed farming project. https://zamboanga.com/z/index.php?title=2,810 fishermen in_Palawan benefit_from_seaweed_farming project Accessed 15 April 2020

Largo DB, Chung IK, Phang SM, Gerung GS, Sondak CFA (2017) Impacts of climate change on Eucheuma-Kappaphycus farming. In: Hurtado AQ, Critchley AT, Neish IC (eds) Tropical seaweed farming trends, problems and opportunities. Springer, Cham, pp $121-129$

Leonardi PI, Miravalles AB, Faugeron S, Flores V, Beltrán J, Correa JA (2006) Diversity, phenomenology and epidemiology of epiphytism in farmed Gracilaria chilensis (Rhodophyta) in northern Chile. Eur J Phycol 41:247-257

Leung TL, Bates AE (2013) More rapid and severe disease outbreaks for aquaculture at the tropics: implications for food security. J Appl Ecol $50: 215-222$

LGU (Local government Unit) (2018) Formulation of ordinance banning the use of inorganic fertilizer http://www.lgupanglimasugala.gov. $\mathrm{ph} / 2018 / 10 / 08 /$ formulation-of-ordinance-banning-the-use-ofinorganic-fertilizer/ Accessed 09 May 2020

Liu H, Xu X, Liu D, Rao Y, Reis C, Sharma M, Yuan J, Chen Y, Zhao Y (2018) Nutrition-related knowledge, attitudes, and practices (KAP) among kindergarten teachers in Chongqing, China: a cross-sectional survey. Int J Environ Res Public Health 15:615

Lotz JM (1997) Viruses, biosecurity and specific pathogen-free stocks in shrimp aquaculture. World J Microbiol Biotechnol 13:405-413

Luhan MRJ, Avañcena SS, Mateo JP (2015) Effect of short-term immersion of Kappaphycus alvarezii (Doty) Doty in high nitrogen on the growth, nitrogen assimilation, carrageenan quality, and occurrence of "ice-ice" disease. J Appl Phycol 27:917-922

Manalo EP (2004) Philippine response to terrorism: The Abu Sayyaf Group. MA Thesis: Naval Post Graduate School, Monterey, California. pp.114 https://fas.org/irp/world/para/manalo.pdf Accessed 07 May 2020
Mateo JP, Campbell I, Cottier-Cook EJ, Luhan MRJ, Ferriols VMEN, Hurtado AQ (2020) Analysis of biosecurity-related policies governing the seaweed industry of the Philippines. J Appl Phycol 32:2009-2022

Mathiesen AM (2019) The progressive management pathway for aquaculture biosecurity (PMP/AB)-a new initiative. $29 \mathrm{pp} \mathrm{https://www.}$ oie.int/aquatic-conference2019/wp-content/uploads/2019/04/6. ArniMathiesen_presentation_FINAL__020419.pdf Accessed 23 May 2020

Matthews GA (2008) Attitudes and behaviours regarding use of crop protection products - a survey of more than 8500 smallholders in 26 countries. Crop Prot 27:834-846

Meijer SS, Catacutan D, Ajayi OC, Sileshi GW, Nieuwenhuis M (2015) The role of knowledge, attitudes and perceptions in the uptake of agricultural and agroforestry innovations among smallholder farmers in sub-Saharan Africa. Int J Agric Sustain 13:40-54

Mirzaei R, Hafezi-Nejad N, Sabagh MS, Moghaddam AA, Eslami V, Rakhshani F, Rahimi-Movaghar V (2014) Dominant role of drivers' attitude in prevention of road traffic crashes: a study on knowledge, attitude, and practice of drivers in Iran. Accid Anal Prev 66:36-42

Msuya FE (2013) Effects of stocking density and additional nutrients on growth of the commercially farmed seaweeds Eucheuma denticulatum and Kappaphycus alvarezii in Zanzibar Tanzania. TaJONAS 4:605-612

Msuya FE, Hurtado AQ (2017) The role of women in seaweed aquaculture in the Western Indian Ocean and South-East Asia. Eur J Phycol $52: 482-494$

Neish IC (2013) Social and economic dimensions of carrageenan seaweed farming in Indonesia. In: Valderrama D, Cai J, Hishamunda $\mathrm{N}$, Ridler N (eds) Social and economic dimensions of carrageenan seaweed farming. Fish Aquaculture Tech Paper No. 580. FAO, Rome, pp 57-85

Pham-Duc P, Cook MA, Cong-Hong H, Nguyen-Thuy H, Padungtod P, Nguyen-Thi H et al (2019) Knowledge, attitudes and practices of livestock and aquaculture producers regarding antimicrobial use and resistance in Vietnam. PLoS One 14:e0223115

Philippines Statistics Authority (PSA) (2013) Selected statistics on agriculture $2013 \mathrm{https} / / \mathrm{psa}$.gov.ph/sites/default/files/Selected\% 20Statistics\%20on\%20Agriculture\%202013.pdf Accessed 19 Apr 2020

Qviller L, Kristoffersen AB, Lyngstad TM, Lillehaug A (2020) Infectious salmon anemia and farm-level culling strategies. Front Vet Sci 6:481

Rahman MZ, Rahman MM (2018) Transboundary fish diseases and control measures in Bangladesh. In: Giri SS (ed) Control of transboundary aquatic animal diseases. SAARC, Dhaka, pp 36-53

Samonte GP (2017) Economics of Kappaphycus spp. seaweed farming with special reference to the Central Philippines. In: Hurtado AQ, Critchley AT, Neish IC (eds) Tropical seaweed farming trends, problems and opportunities. Springer, Cham, pp 147-154

Sanz VA (2018) Specific pathogen free (SPF), specific pathogen resistant (SPR) and specific pathogen tolerant (SPT) as part of the biosecurity strategy for whiteleg shrimp (Penaeus vannamei Boone 1931). Asian Fish Soc 31:112-120

Sherman A, Trisi D, Parrott S (2013) Various supports for low-income families reduce poverty and have long-term positive effects on families and children. Center on Budget and Policy Priorities. Washington DC. 19pp

Smith JE, Hunter CL, Smith CM (2002) Distribution and reproductive characteristics of nonindigenous and invasive marine algae in the Hawaiian Islands. Pac Sci 56:299-315

Srinivasan NK, John D, Rebekah G, Kujur ES, Paul P, John SS (2017) Diabetes and diabetic retinopathy: knowledge, attitude, practice (KAP) among diabetic patients in a tertiary eye care centre. J Clin Diagn Res 11:NC01

Subasinghe RP, Curry D, McGladdery SE, Bartley D (2003) Recent technological innovations in aquaculture. FAO Fish Circ 886:85 
Sulu R, Kumar L, Hay C, Pickering T (2004) Kappaphycus seaweed in the Pacific: review of introductions and field testing proposed quarantine protocols. Secretariat of the Pacific Community, Noumea $85 \mathrm{pp}$

Suyo JGB, Le Masson V, Shaxson L, Luhan MRJ, Hurtado AQ (2020) A social network analysis of the Philippine seaweed farming industry: Unravelling the web. Mar Policy 118:104007

Tendencia EA, Estilo VE (2017) Advocating preventive measures that inhibit early mortality syndrome in shrimps. Secretariat, Southeast Asian Fisheries Development Center, Fish for the People 15:30-36

Tidbury HJ, Joiner CL, Rimmer GS, Potter HV, Taylor NG (2018) The effectiveness of fishery net dips: advice for the improvement of biosecurity measures. J Fish Dis 41:1625-1630

Tran H, Nguyen Q, Kervyn M (2018) Factors influencing people's knowledge, attitude, and practice in land use dynamics: a case study in Ca Mau province in the Mekong delta, Vietnam. Land Use Policy 72:227-238

Tsiresy G, Preux J, Latriva T, Dubois P, Lepoint G, Eeckhaut I (2016) Phenology of farmed seaweed Kappaphycus alvarezii infestation by the parasitic epiphyte Polysiphonia sp. in Madagascar. J Appl Phycol 28:2903-2914

Umanzor S, Shin S, Marty-Rivera M, Simona Augyte S, Yarish C, Kim JK (2019) Preliminary assessment on the effects of the commercial seaweed extract, AMPEP, on growth and thermal tolerance of the kelp Saccharina spp. from the Northwest Atlantic. J Appl Phycol 31:3823-3829

Vairappan CS, Chung CS, Hurtado AQ, Msuya FE, Bleicher Lhonneur G, Critchley A (2008) Distribution and symptoms of epiphyte infection in major carrageenophyte-producing farms. J Appl Phycol 20:477-483

Valderrama D, Cai J, Hishamunda N, Ridler N (2013) Social and economic dimensions of carrageenan seaweed farming. Fisheries and Aquaculture Technical Paper No. 580. FAO, Rome 204pp

Valderrama D, Cai J, Hishamunda N, Ridler N, Neish IC, Hurtado AQ, Msuya FE, Krishnan M, Narayanakumar R, Kronen M, Robledo D (2015) The economics of Kappaphycus seaweed cultivation in developing countries: a comparative analysis of farming systems. Aquac Econ Manag 19:251-277

Walker PJ, Mohan CV (2009) Viral disease emergence in shrimp aquaculture: origins, impact and the effectiveness of health management strategies. Rev Aquac 1:125-154

Werkman M, Green DM, Murray AG, Turnbull JF (2011) The effectiveness of fallowing strategies in disease control in salmon aquaculture assessed with an SIS model. Prev Vet Med 98:64-73

Wittenberg R, Cock MJW (2001) Invasive alien species. How to address one of the greatest threats to biodiversity: a toolkit of best prevention and management practices. CAB International, Wallingford 229pp

Zhang J (2018) Seaweed industry in China. Obtenido de Innovation Norway China: https://algenett.no/sites/a/algenett.no/files/ seaweed_china_2018.pdf. 31pp Accessed 29 Jul 2020

Publisher's note Springer Nature remains neutral with regard to jurisdictional claims in published maps and institutional affiliations. 